\title{
Kompleks Pengembangan Garam Terpadu Surabaya
}

\author{
Irfan Falih Mahdi dan Bambang Soemardiono \\ Departemen Arsitektur, Fakultas Arsitektur, Desain dan Perencanaan, Institut Teknologi Sepuluh Nopember (ITS) \\ e-mail: bbsoem@arch.its.ac.id
}

\begin{abstract}
Abstrak-Surabaya merupakan salah satu kota terbesar di Indonesia yang berada di daerah pesisir. Sehingga Surabaya berpotensi untuk menjadi daerah penghasil garam yang besar. Namun berbanding terbalik dengan kondisi Indonesia dan khusunya Surabaya sekarang yang sedang mangalami krisis garam. Arsitektur bioklimatik mengajarkan kita akan pentingnya merespon iklim agar arsitektur yang kita rancang dapat sesuai dengan kebutuhan. Diperlukannya metode yang menerapkan prinsip-prinsip arsitektur bioklimatik yaitu dapat memanfaatkan potensi-potensi sekitar site dengan memperhatikan konfigurasi bentuk massa bangunan dan perencanaan tapak, orientasi bangunan, ruang transisional, desain pada dinding, hubungan terhadap lansekap. Program pada rancangan ini memliki program utama yakni Industri, Hunian, serta Edukasi. Seluruh program tersebut akan disatukan dan memiliki integrasi satu sama lain. Programprogram tersebut di rancang untuk dapat menjawab permasalahan yang sedang terjadi dan diharapkan kepedulian dan partisipatif dari berbagai pihak dapat menjaga eksistensi garam di Surabaya.
\end{abstract}

Kata Kunci-Arsitektur Bioklimatik, Garam, Iklim, Pengembangan, Terpadu.

\section{PENDAHULUAN}

$\mathrm{P}$ EMANFAATAN garam di Indonesia sejatinya dapat dimanfaatkan semaksimal mungkin. Indonesia berpotensi untuk menjadi penghasil garam yang besar karena memiliki garis pantai yang cukup luas. Namun potensi ini tidak diimbangi dengan peningkatan jumlah dan mutu produksi garam di Indonesia. Keadaan ini terjadi di setiap wilayah negara Indonesia termasuk Surabaya yang merupakan kota pesisir pantai dan salah satu kota terbesar di Indonesia. Peran fungsi garam bisa dibilang sangat penting bagi kehidupan manusia karena garam tidak hanya dijadikan sebagai kebutuhan konsumsi namun Sekitar $40 \%$ hasil olahan garam di dunia digunakan pada proses industri. Garam merupakan bahan baku kimia yang nantinya akan diubah menjadi klorin dan soda abu, serta dasar-dasar kimia anorganik. Garam dijadikan sebagai bahan baku dalam berbagai industri seperti karet, kaca, kain, dll.

Sektor industri garam di Surabaya masih jauh dari kata profesional, dikarenakan masih melakukan cara tradisional dan skala kecil. Tidak terdapat pola integrasi yang bagus di proses industri garam Surabaya.

Faktor yang lainnya adalah faktor iklim dan cuaca. Masyarakat khusunya petani garam masih sangat bergantung pada sinar matahari untuk proses penguapannya serta kurangnya kepedulian terhadap garam itu sendiri. Oleh karena itu pentingnya edukasi dan partisipasi aktif dari berbagai bidang ilmu untuk diterapkan guna menanggulangi masalah tersebut.

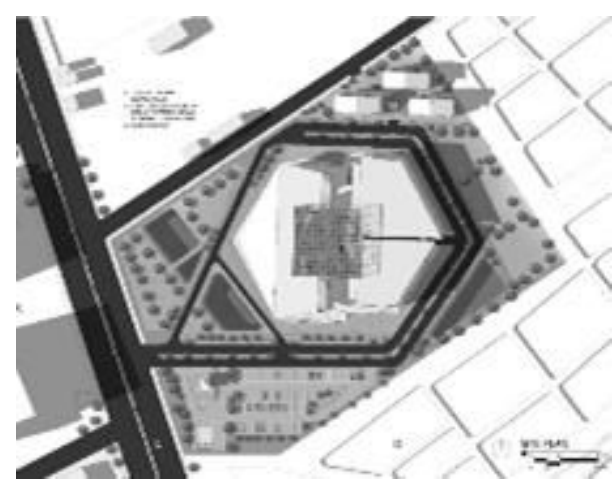

Gambar 1. Site Plan Kompleks Pengembangan Garam Terpadu Surabaya.

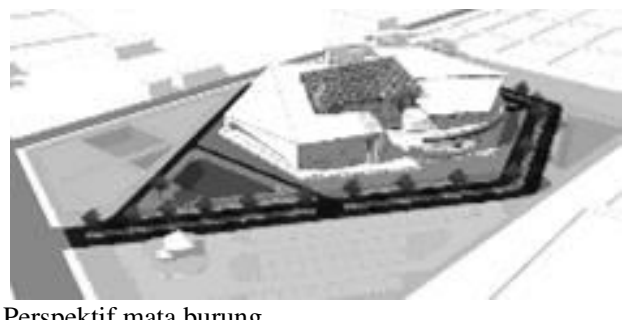

Gambar 2. Perspektif mata burung.

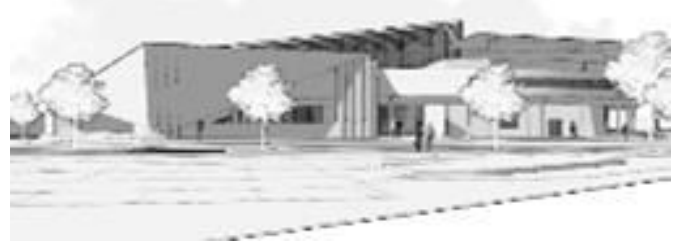

Gambar 3. Perspektif mata orang.

Iklim khususnya matahari sangat berpengaruh bagi industri garam menyebabkan hal tersebut menjadi faktor terpenting dalam proses produksi garam. Karena jika tidak ada iklim yang pasti maka industri garam di Indonesia akan mengalami krisis produksi. Terlebih pada saat ini iklim mikro di Indonesia sudah sulit untuk diprediksi.

Pada dasarnya sirkulasi dan integrasi dari program di berbagai macam pabrik atau industri garam di Indonesia belum terigentrasi secara baik. Dikarenakan proses produksi sangat penting, oleh karena itu adanya sistem integrasi yang baik dibutuhkan untuk mencapai proses produksi yang berkala dan berkelanjutan. Seperti contoh tempat proses produksi garam yang berjauhan dengan tempat pemprosesan selanjutnya yang berakibat memakan waktu dan biaya produksi lebih. 


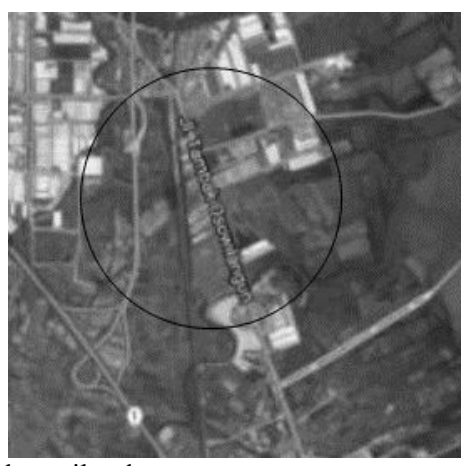

Gambar 4. Foto udara wilayah perancangan.

(Sumber : olahan dari : https://www.google.co.id/maps/.com)
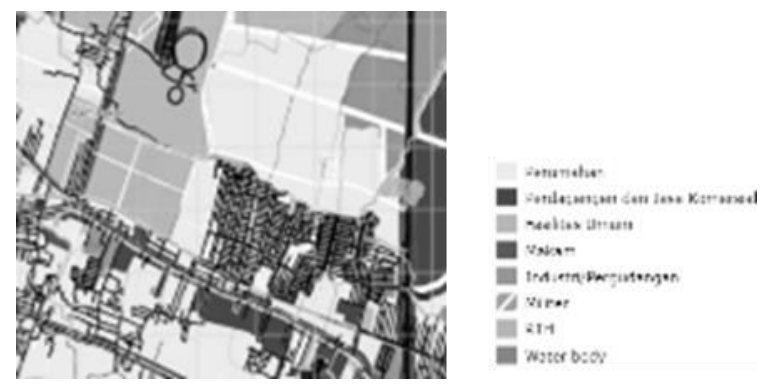

Gambar 5. Foto peta peruntukan daerah Pakal dan Benowo Surabaya. (Sumber : olahan dari : http://petaperuntukan.surabaya.go.id/cktr-map/)

Terlebih perkembangan garam sebenarnya tidak terlepas dari peran aktif dari masyarakat luas. Garam merupakan salah satu bahan dasar utama dalam kehidupan manusia. Kita ketahui banyak manfaat dan kegunaan yang diperoleh dari garam. Oleh karena itu dibutuhkan berbagai macam lapisan masyarakat yang dapat berperan aktif untuk terus mengembangkan potensi garam yang ada di Indonesia, Hal tersebut dapat dimulai dari kota Surabaya yang memiliki banyak potensi untuk mengembangkan garam itu sendiri. Namun peran aktif dari masyarakat luas tentang perkembangan garam dirasa sangat kurang. Faktor edukasi untuk menambah pengetahuan masyarakat terhadap garam dirasa perlu untuk memicu masyarakat untuk terus mengembangkan garam di Indonesia khususnya Surabaya.

Menurut data peta peruntukan Surabaya lahan garam yang terdapat di Benowo dan Pakal akan mengalami penyempitan dikarenakan kedepan sebagian besar lahan akan di gunakan sebagai perumahan. Maka dari itu dengan adanya rencana tersebut pasti produksi garam di wilayah Surabaya pasti akan mengalami penurunan yang signifikan.

Sebagai kota metropolitan Surabaya berkembang menjadi kota yang dengan modernitas yang tinggi, namun kota Surabaya masih memiliki daerah sawah garam yang terbilang besar. Namun modernitas untuk menunjang pertumbuhan sumber daya alam khususnya garam masih kurang. Sehingga mereka masih mengandalkan cara tradisional dalam bertani garam. Lingkup perancangan kali ini adalah ruang publik yang dapat menaungi aktivitas-aktivitas mulai dari proses produksi, sampai distribusi serta edukasi. Kecamatan benowo adalah sebuah kecamatan di kota Surabaya. Kecamatan ini merupakan kecamatan terluas di Surabaya.

Adapun batasan wilayah perancangan kali ini adalah daerah lahan garam yang terdapat di Surabaya. Tepatnya di daerah sebelah barat kota Surabaya. Daerah tersebut memiliki lahan garam yang cukup luas sehingga cocok dengan industri garam.

Lahan garam di surabaya seperti ladang garam-ladang garam yang ada di Indonesia. Menurut website pemerintah

Tabel 1

Luas Kesesuaian Tata Guna Lahan Wilayah Surabaya Barat Tahun 2009 dengan RDTRK Surabaya Tahun 2009 (per-Kecamatan).

\begin{tabular}{cc}
\hline \hline Kecamatan & $\begin{array}{c}\text { Luas Guna Lahan Belum } \\
\text { dimanfaatkan (\%) }\end{array}$ \\
\hline Pakal dan Benowo & 16.83 \\
Asemrowo & 27.84 \\
Sukomanunggal & 22.98 \\
Tandes & 47.65 \\
Sambikerep dan Lakarsantri & 33.83 \\
\hline \hline : Peraturan daerah kota Surabaya No. 03 Tahun. 2007 Tentang
\end{tabular}
Rencana Tata Ruang Wilayah Kota Surabaya Tahun 2010-2030.
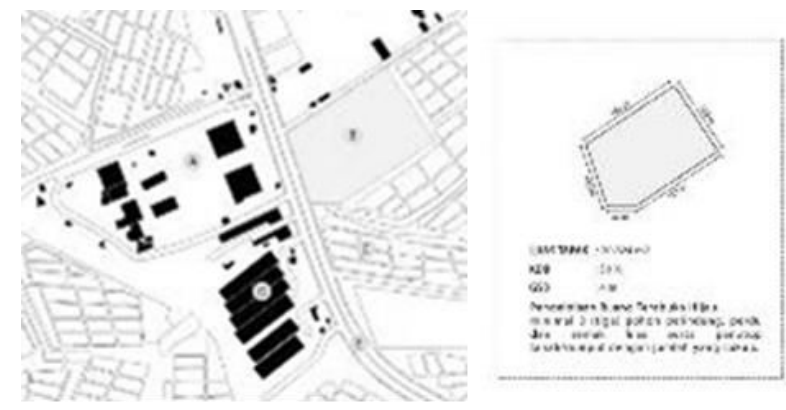

Gambar 6. Lokasi dan luas tapak

kota Surabaya lahan garam di surabaya mencakup 623 Ha. Luas tersebut terbagi di 3 kecamatan yakni kecamatan Benowo dengan luas $330.87 \mathrm{Ha}$ dengan 79 petani, kecamatan Pakal dengan luas 267.28 Ha dengan 41 petani, dan kecamatan Asemrowo $25.5 \mathrm{Ha}$ dengan 4 petani. Lahan garam berupa hamparan tanah ksosong yang berpetak yang di dalamnya ada proses penguapan untuk mengkristalkan garam yang berasal dari air laut yang pompa.

Lahan garam yang ada di Surabaya masih dapat terus dimanfaatkan sebagai penghasil garam dengan modifikasi dan inovasi-inovasi yang harus terus dilakukan. Agar lahan garam yang ada di Surabaya tidak dialih fungsikan. Karena fakta menyebutkan bahwa lahan garam di Surabaya semakin harisemakin menipis karena menurunnya produksi garam serta rendahnya kepedulian tentang komoditi garam di kota Surabaya.

Lahan garam yang berada di Surabaya merupakan lahan garam para petani garam yang dikelola oleh beberapa kelompok petani garam yang ada. Lahan seluas 267.28 Ha sekiranya cukup untuk memproduksi dan menutupi kebutuhan konsumen garam warga Surabaya. Ternyata tidak. Lahan tersebut akhir-akhir ini banyak mengalami kekosongan produksi dikarenakan musim hujan yang terus menerus mengguyur daerah tersebut pada tahun 2016 silam. Lahan garam yang dibuat juga ala kadarnya, berasal dari tanah yang di coak berbentuk petak-petak kemudian dialiri air laut dengan pompa yag akhirnya lahan tersebut menjadi tempat penguapan air garam serta tempat kristalisasi air laut menjadi garam. 
Mayoritas pengguna yang memanfaatkan daerah tersebut adalah petani garam yang mengolah sawahnya untuk memproduksi garam. Tapi di daerah Benowo terdapat terminal yang para penggunanya merupakan orang yang menawarkan

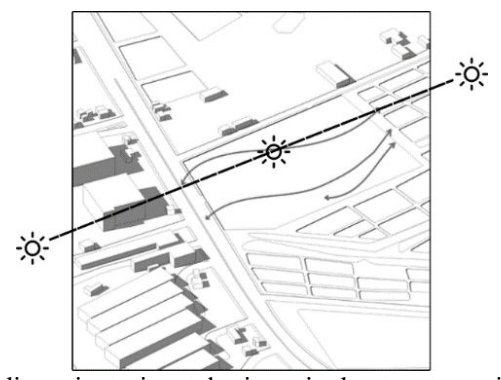

Gambar 8. Analisa orientasi matahari, angin darat serta angin laut.

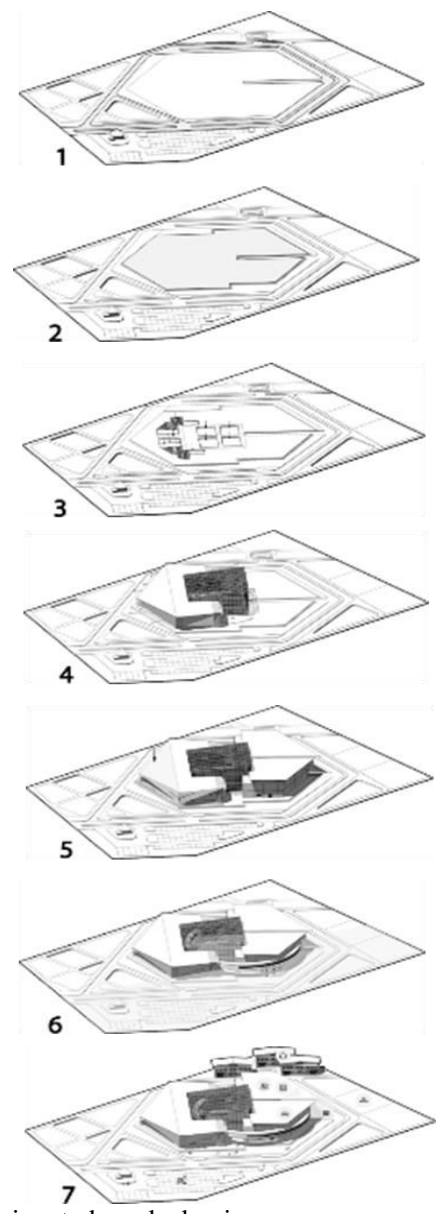

Gambar 9. Aplikasi metode pada desain.

jasa transportasi dan pengunjungpun datang dari berbagai macam daerah hanya untuk singgah.

Dalam kesempatan ini, penulis berusaha merancang sebuah desain arsitektur yang dapat merespon iklim mikro dan mengintegrasikan program-program serta pola sirkulasi yang dapat mempermudah proses produksi garam. Data iklim mikro menunjukkan bahwa suhu temperatur di sekitar tapak sangat mendukung,berkisar 28 derajat celcius namun intensitas hujan yang tidak menentu yang menyebabkan kesulitan memproduksi garam.

\section{METODA PERANCANGAN}

Terdapat proses desain yang rasional yaitu basa disebut glass box serta arsitektur merupakan produk dari proses yang rasional, empirik. Terdapat tiga macam tipe proses yakni analisis, sintesis, serta evaluasi [1]. Pada tahap analisis

Tabel 2.

Temperatur Kecamatan Benowo Surabaya dalam 1 Tahun

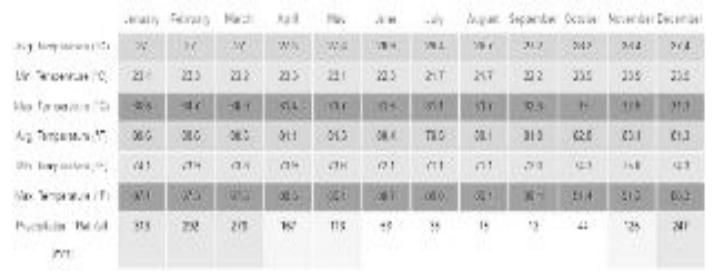

Sumber : https://id.climate-data.org/location/614398/

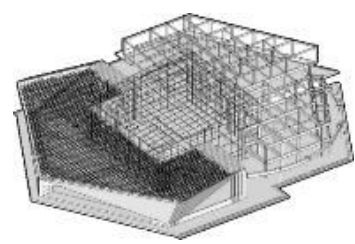

Gambar 10. Sistem struktur

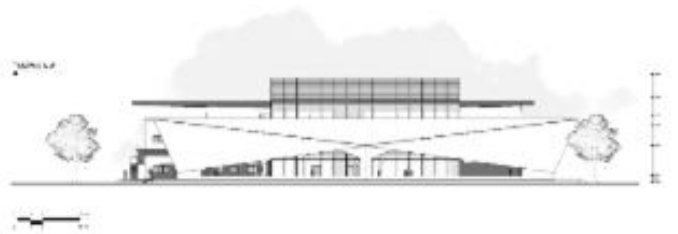

Gambar 11. Tampak A.

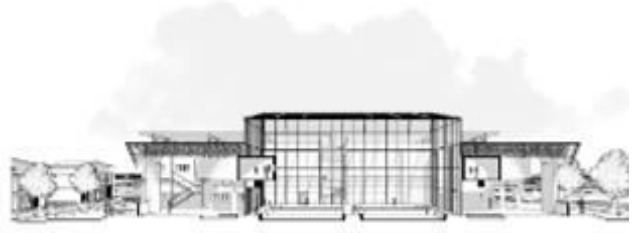

gemas

Gambar 12. Potongan A.

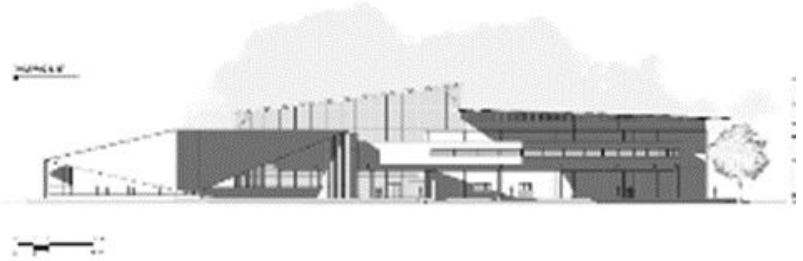

Gambar 13. Tampak B.

didapatkan data-data analisa tapak, analisa site, serta analisa objek rancang. Selanjutnya tahap sintesis didapatkan kriteriakriteria desain yang kemudian dapat ditentukan konsep yang sesuai dengan objek rancang dengan metode berdasarkan arsitektur biolkimatik.

Arsitektur bioklimatik mengarahkan arsitek untuk melakukan penyelesaian desain dengan mempertimbangkan hubungan antara bentuk arsitektur dengan lingkungannya, dalam hal ini, iklim daerah tersebut. Pendekatan ini nantinya juga dapat menghemat konsumsi energi bangunan [2]. Prinsip desain bioklimatik menurut harus memperhatikan Penentuan Orientasi, Membuat ruang transisional, Desain Pada Dinding, 
Hubungan Terhadap Landscape, Penggunaan Alat Pembayang Pasif [3].

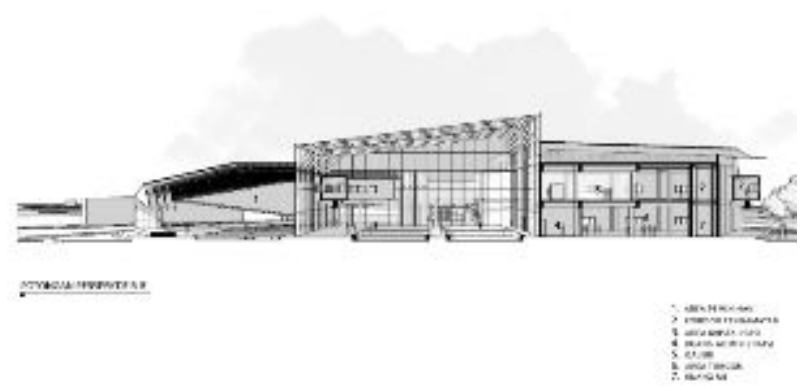

Gambar 14. Potongan B.

Efisiensi energi sebenarnya bukanlah meupakan kriteria baru dalam disain arsitektur. Konteks keberadaan suatu bangunan selalu ditentukan oleh batasan batasan iklim dan material bangunan. Sepanjang sejarah, iklim, energi dan kebutuhan kebutuhan sumber daya merupakan hal hal fundamental dalam seni dan tatanan arsitektur.

Bahkan dalam kondisi kondisi iklim yang ekstrim sekalipun tidak menghalangi para perancangnya untuk menghadirkan karya arsitektur anggun yang merupakan solusi atas permasalahan lingkungannya. Arsitektur Surya (Solar Architecture) Arsitektur yang memanfaatkan energi surya baik secara langsung (radiasi cahaya dan termal), maupun secara tidak langsung (energi angin) kedalam bangunan, dimana elemen-elemen ruang arsitektur (lantai,dinding,atap) secara integratif berfungsi sebagai sistim surya aktif ataupun sistim surya pasif [4]. Beberapa tahap perancangan akan dievaluasi menggunakan metode evaluatif yang dapat mensimulasikan hasil desain. Bertujuan untuk mengukur keberhasilan desain dalam menyelesaikan permasalahan.

\section{HASIL PERANCANGAN}

Objek rancang yang memanfaatkan iklim untuk menunjang proses penggaraman diperlukan orientasi bangunan yang sesuai dengan arah terbit dan terbeneam matahari agar bangunan selalu terpapar sinar matahari langsung. Serta memanfaatkan laju dari angin darat dan angin laut yang diperlukan pada proses peminihan dan proses penghawaan di sekitar area Industri. Menentukan area terbuka dan tertutup dikarenakan proses solar evaporation yang membutuhkan keadaan khusus. Area kristalisasi sebagai pembentuk butiran garam memerlukan kedaan khusus berupa penyinaran matahari secara langsung dan tidak memerlukan banyak angina, sehingga memberikan zona tertutup dengan material kaca tempered agar sinar matahari dapat masuk secara langsung dan sudut yang menghadap ke arah matahari ketika siang dan menjelang sore dikarenakan intensitas sianr matahari lebih panas pada waktu tersebut. Bukaan terdapat pada area pemininihan diakarenakan memanfaatkan laju angin darat dan angin laut yang dapat memnunjang proses pada pengaliran air laut menjadi lebih pekat kadar garamnya sehingga ketika air memasuki zona kristalisasi didapatkan kadar garam yang sesuai dan terjaga kualitas garam yang ditentukan.

Membedakan area industri dengan area penunjang dengan memperhatikan analisa geometri dan didapatkan bentuk segi enam, dikarenakan geometri segi enam dapat terbagi antara area yang terpapar dan area yang sedikit terpapar sinar

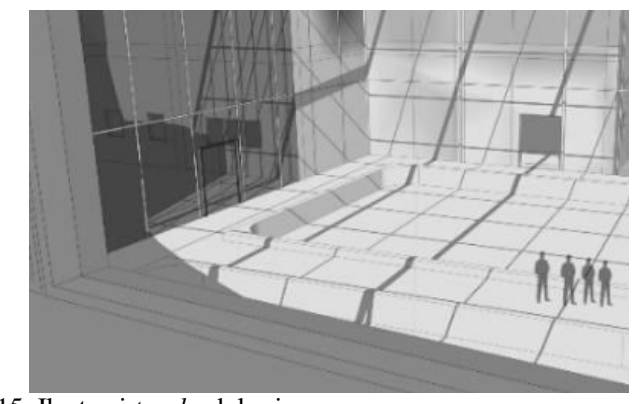

Gambar 15. Ilustrasi track edukasi.

matahari. Bagian yang terpapar matahari di rancang untuk proses industri dan area yang sedikit terpapar sinar matahari dirancang untuk area penunjang bagi masyarakat umum. Dengan pembedaan program pada objek rancang maka struktur juga didesain agar sesuai dengan kebutuhan program. Area peminihan yang terdapat pada zona industri dirancang dengan struktur space frame sebab dibutuhkan area yang luas, lebar, bebas kolom, dan megikuti bentuk dari area tersebut. Pada area kristalisasi yang didesain dengan material kaca tempered maka struktur yang duginakan adalah struktur dari kaca tempered yang didesain sebagai struktur dengan penopang dan sambungan berupa baja dan besi. Dan Area pada area penunjang dan area edukasi memilki struktur yang bermaterial beton diakrenakan memilki sifat kokoh dan terdapat beban diatasnya, serta menimbulkan kesan massif. Pada area penunang struktur berpola grid sedangkan pada area edukasi struktur menggunakan struktur akantilever karena track pada area edukasi dapat ditopang dengan satu kolom dan melingkar. Pola radial yang didesain untuk menjadikan program industri sebagai pusat dari segala aktivitas program di objek rancang. Dan program-program yang lain berada di sekitar area industri seperti hunian dan edukasi. Edukasi di tempatkan pada layer kedua objek rancang diharapkan masyarakat dapat memperhatikan proses penggaraman dari proses awal hingga proses distribusi secara seksama, serta masyarakat dapat melihat tambak-tambak garam yang biasa digunakan oleh petani garam memanen garam secara konvensional.

\section{KESIMPULAN}

Pada rancangan Kompleks Pengembangan Garam Terpadu Surabaya ini dapat kita ketahui bahwa dengan memodifikasi elemen-elemen arsitektur berdasarkan prinsip arsitektur bioklimatik maka kita dapat memanfaatkan iklim mikro untuk memudahkan kita dalam mencapai kemajuan dalamberbagai bidang kehidupan, menciptakan inovasi untuk teru mengembangkan potensi serta memecahkan masalah yang terdapat pada tapak dan lingkungan sekitar, dapat memberikan dampak positif terhadap lingkungan sekitar dan pada tujuan akhir menjadikan objek rancang yang berkelanjutan. Oleh karena itu pengembangan dan pemanfaatan potensi garam serta keterlibatan masyarakat luas untuk berpartisipasi dalam menjaga kelestarian garam surabaya akan terus berkembang. 


\section{DAFTAR PUSTAKA}

[1] C. Jones, Design Methods. New York: John Wiley \& Sons, 1992.

[2] F. Dewangga and P. Setijanti, "Pendekatan Arsitektur Bioklimatik Pada Bangunan Pesisir," J. Sains dan Seni ITS, vol. 5, no. 2, pp. 184-187, 2016.

[3] K. Yeang, Bioclimatic Skyscraper. London: Artemis, 1994.

[4] J. Priatman, "Energy-efficient architecture," J. Archit. Built Environ. Dimens., vol. 30, no. 2, pp. 167-176, 2002. 